\title{
The Concept of Mixed Migration Flows and International Legal Regulation of Migration
}

\author{
Ekaterina V. Kiseleva \\ Candidate of Legal of Sciences (PhD), Associate Professor \\ Department of International Law, Law Institute, Peoples' \\ Friendship University of Russia (RUDN University), 6 \\ Miklukho-Maklaya st., Moscow, 117198, Russia \\ E-mail: kiseleva_ev@rudn.university
}

\author{
Egor E. Markin \\ Post-Graduate, Department of International Law, Law \\ Institute, Peoples' Friendship University of Russia (RUDN \\ University), 6 Miklukho-Maklaya st., Moscow, 117198, \\ Russia
}

\begin{abstract}
The concept of mixed migration flows is one of the key components of the comprehensive approach to international legal regulation of migration. Whereas international cooperation on the issues of migration has its most considerable outcomes in specific fields, not in the overall view or framework for international legal regulation of migration taken as a whole, differentiating between flows, that are governed separately, represents for states more a subject of concern than that of clarity and action. The present article offers a view on the emergence, evolution, application in the practice of the leading specialized international interstate organizations and prospectives of the further development of the mixed migration flows concept, elaborated on basis of relevant normative and doctrinal sources including the most recent ones.
\end{abstract}

Keywords-International law; Migration; Mixed migration flows; UNHCR - United Nations High Commissioner for Refugees; IOM - International Organization for Migration

\section{INTRODUCTION}

The Oxford dictionary defines migration as "movement of people to a new area or country in order to find work or better living conditions" [1]. The International Organization for Migration (hereinafter IOM) defines migration as "a process of moving, either across an international border, or within a State. It is a population movement, encompassing any kind of movement of people, whatever its length, composition and causes; it includes migration of refugees, displaced persons, uprooted people, and economic migrants" [2, p. 67].

Migration is not a new phenomenon. From the times of the earliest nomadic hunters, traders and explorers the mobility of people has been a constant throughout history.

Mobility comes in a variety of forms, ranging from that of students to refugees, from that of economic migrants to victims of human trafficking. As the United Nations General Assembly (hereinafter UN GA) noted in its resolution 71/1 adopted as an outcome of the New York Summit for refugees and migrants, 19 September, 2016, we are witnessing in today's world an unprecedented level of human mobility. More people than ever before live in a country other than the one in which they were born. Migrants are present in all

The article was prepared in frames of the Project 16-03-50188 supported by the Russian Foundation for Humanities. countries in the world. Most of them move without incident. In 2015, their number surpassed 244 million, growing at a rate a bit faster than the world's population. However, there are roughly 65 million forcibly displaced persons, including over 21 million refugees, 3 million asylum seekers and over 40 million internally displaced persons.

This overwhelming flow of migrants, growth of mobility in "scale, scope and complexity" causes a number of challenges for international community and, thus, to international law as an instrument assisting states to reach their agreed goals [3, p. 3]. New concepts have been developed to address these difficulties.

One relatively new term that has emerged in the migration and refugee discourse within the last decade is "mixed migration'. Mixed migration is a collective concept which includes all the types of migration. Mixed flows are defined as complex population movements including refugees, asylum seekers, economic migrants and other migrants [2, p. 119].

\section{RoOTS OF THE 'MiXED MigRATION Flows' CONCEPT}

In order to understand the development and significance of the term 'mixed migration', it is essential to set the concept's emergence within its historical context.

The mixed migration label has its roots in the development of the global governance system conceived in the aftermath of the Second World War (hereinafter WWII). The period following WWII was marked by an upsurge in migration as many in Europe were displaced and in need of protection and assistance [4]. In response, an international system was developed to address the needs of those displaced and to answer government calls for order to be restored [5, $\mathrm{p}$. 34]. As part of these efforts, an attempt of clear legal separation between refugees and migrants was taken. This appeared with the signing of the 1951 Refugee Convention and later 1967 Protocol. To this day, these documents are pivotal human rights instruments that establish the international obligation to protect refugees from persecution, prevent their refoulement and guarantee their wider rights $[6$, p. 161].

Another critical development of the same decades was the recruitment by industrial countries of temporary guest workers 
to satisfy the need for manual labour [7, p. 29]. However, guest workers were "wanted but not welcome" and it was believed that they would only stay for a temporary period of time [8]. The oil crisis in 1973 slowed growth in the Global North and drastically reduced the need for guest workers $[9, \mathrm{p}$. 9]. Instead of returning to their countries of origin, however, many guest workers stayed and used established networks to bring over their families despite numerous countries adopting a policy of "zero-immigration" [9, p. 17]. This marked a turning point in the relationship between states of the Global North and migrant workers. From the early 1970s onwards, many states in the Global North severely restricted regular migration channels.

These developments had significant repercussions. While the original supply-demand dynamics remained, the regular channels for this movement of economic migrants no longer existed [10, p. 17]. The only viable options for regular migration remained through family connections and through the asylum system. This resulted in the number of asylum seekers in the EU and other areas of the Global North increasing during the 1980s and 1990s [7, p. 35].

The increase in number of asylum seekers to the Global North was accompanied by a steady rise in anti-immigration sentiment as well as increasing skepticism as to whether those claiming asylum were in fact "genuine" refugees[11]. Government officials, and many among the general public, expressed concern that a considerable number of asylum seekers were in reality economic migrants taking advantage of the international refugee system. In the Global North the image of the 'bogus refugee' gained prominence [12]. In the 1990s and early 2000s refugees and asylum seekers were often seen as part of the unwelcome increase in irregular migration.

While shifts in attitudes towards asylum seekers and migrants were prompted by numerous factors, scholars point to three critical turning points: the signing of the Schengen Agreement; the collapse of the Soviet Union; and the terrorist attacks on September 11th 2001 [13; 9, p. 17; 5, p. 7; 11; 14].

Accompanying these three critical moments in migration and asylum discourse was the overarching developments in communication and transportation. Over a short time, far-off events could impact the Global North with unprecedented speed. This helped to cultivate a sense of insecurity that drove further migration and asylum restrictions [15].

Such dramatic dynamics attracted the attention of scholars who advocated the inadequacy of the migrant classification system. Many vocally raised doubts as to whether the current refugee-migration system did justice to the complexity of factors driving the movement of people [16]. Scholars explored the inter-linkages between 'choice' and 'compulsion' and concluded that "few migrants are wholly voluntary or wholly forced" [16]. They argued that the co-existence of poverty, conflict, environmental degradation and social and political inequality made mutually exclusive categories inadequate. It was reasoned that classification systems are not based on "rigorous scientific categories" but are instead the result of "political negotiations and subject to divisions based on certain political and legal requirements" [17].
In 2000, UNHCR declared a global 'crisis' in the international asylum-refugee system. It highlighted that "shrinking asylum space, mostly but not exclusively in the developed world" had led to increasing difficulty for UNHCR fulfil its mandate [18]. Many scholars highlighted that the Global North promoted the moral and legal responsibility of states to protect asylum seekers and refugees while simultaneously implementing preventative measures to them reaching state borders [19].

The situation was compounded by the fact that many states in the Global South were threatening to restrict their policies towards refugees and asylum seekers in reaction to the Global North's lack of 'burden sharing' [20]. Ruud Lubbers, the Higher Commissioner for Refugees in 2002 argued that "while UNHCR supports measures to combat the misuse of asylum systems" the organisation is deeply concerned that "indiscriminate measures have led to non-admission, denial of access to asylum procedures, and even incidents of refoulement" [21].

Within this tense environment the concept of the 'asylummigration nexus' or simply the "nexus question" emerged.

\section{III. 'Mixed MigRation Flows' CONCEPT IN PRACTICE OF THE UNHCR AND IOM}

\section{A. $U N H C R$}

The asylum-migration nexus focused on the categories of migrant and asylum seeker and how the distinctions between the two were increasingly being blurred, or ignored, by states. The term was a key concept in UNHCR's 2002 'Agenda for Protection' in which it highlighted the clear separation between refugees and migrants. The asylum-migration nexus became a fixture in official policy documents, reports and conferences. It was a byword for threats posed to the asylum system by governments not recognising the legitimate claims to asylum of some people moving in irregular flows. The UN High Commissioner for Refugees stated that "protection is at the centre of the new emphasis given to... the asylummigration nexus, where we have an obvious role to play". In October 2003 the term 'asylum-migration nexus' took centrestage in UNHCR's report to the UN General Assembly. In the report UNHCR highlighted the growing restrictions on refugees claiming and receiving protection and called for international commitment to ensure that the asylum system is "kept in good working order and, where necessary, improved". UNHCR declared that it would adjust both its "thinking and its programs so as to better manage both migration and refugee protection challenges, at the nexus where they intersect".

This focus of the asylum-migration nexus culminated in a report submitted in June 2007 by the UNHCR to its governing body, the Executive Committee, titled 'Activities Relating to the Asylum-Migration Nexus'. However, 9 months after this report was released, UNHCR started to distance itself from the term and instead turned to the concept of 'mixed migration'.

The year 2007 marked a shift in UNHCR's terminology from the 'asylum-migration nexus' to 'mixed migration'. Jeff Crisp in 2008 noted the Organization's “serious intentions in 
adopting this new vocabulary", the change in terminology as, in part, a reaction to the negative connotations that the 'asylum-migration nexus' had developed. To UNHCR's dismay, the term was reinforcing the false perception in the Global North that the majority of people on the move were heading towards the developed regions. In reality, as many migrants and refugees stay within their regions of origin.

In addition, the 'asylum-migration nexus' was viewed by many as only representing the interests and concerns of the Global North. This term had come to denote issues of irregular migration, border controls and admission of asylum seekers to their borders. Thus, although the 'asylum-migration nexus' had been readily adopted by stakeholders, it had evolved from its original meaning to one which conflicted with UNHCR's mandate and original intentions.

A key turning point came during the 'Dialogue on Protection Challenges' convened by UNHCR in December 2007. Meeting with fellow stakeholders, UNHCR used the occasion to change the content of the debate. Under the banner of 'refugee protection, durable solutions and international migration' UNHCR asked participants to consider the challenges and solution of "today's mixed movements of migrants and refugees". The move to incorporate "mixed migration' into international migration-refugee discourse was epitomised by UNHCR's core strategy to address refugee protection in mixed flows through its 'Mixed Migration: 10 Point Plan of Action'. This move signaled the centrality of 'mixed migration' as a concept that would play a pivotal role in addressing contemporary challenges derived from "new patterns of movement... that are not addressed by international refugee law".

Despite this pointed shift in terminology, the challenge to refugee and asylum seeker protection that UNHCR is trying to address remains relatively similar as to that under the asylummigration nexus.

\section{B. IOM}

While UNHCR initially conceived of the term 'mixed migration', the IOM has been critical in promoting the concept and in advancing the surrounding discourse and action.

In the years following UNHCR's 2007 Dialogue on Protection Challenges, the IOM developed its own documents on mixed migration which laid out how the IOM saw its position within this discourse. The 2008 Ninety-Sixth Session report focused on the issue of mixed migration as did the subsequent 2009 report in which the IOM defined mixed migration as "complex population movements including refugees, asylum seekers, economic migrants and other migrants" [22].

The following year the IOM published its report 'Irregular Migration and Mixed Flows: IOM's Approach'. In 2010 the IOM released its World Migration Report titled 'Irregular Migration and Mixed Flows'. These documents formed the basis of the IOM's approach to mixed migration.

The term's continued relevance within the IOM is evident when reading through its recent Regional Strategy reports, where mixed migration is stated as one of the IOM's 'Areas for Strategic Intervention', e.g. the IOM specifically notes in its 2013 report for the East and Horn of Africa that mixed migration often occurs in irregular channels and that these flows comprise a wide array of groups of people. These include: refugees, asylum-seekers, displaced persons, as well as migrants pursuing family reunification, education, or employment [23]. In addition to these reports, the IOM promotes the use of the term 'mixed migration' through the regional meetings it hosts with UNHCR. The continued use of the term was demonstrated recently during the IOM and UNHCR's May 2014 meeting in which they worked with regional stakeholders in Mozambique to discuss issues of mixed migration [24].

The IOM's adoption of the term 'mixed migration' can also be seen in the organization's Global 12-Point Strategy. It was developed in 2007 to enable the IOM to address the increasing challenges of migration through a "holistic" approach that would provide the IOM with institutional flexibility to further integrate collaboration with strategic partners into its practices. It is interesting to note that in the same year that UNHCR brought forward its 10-Point Plan of Action to address mixed migration, the IOM also marked a time of transition through its Global 12-Point Strategy. Within the Global 12-Point Strategy the IOM refers specifically to mixed migration. Through these references, the IOM demonstrates how the challenge of mixed migration fits directly with its sphere of work as laid out in its Constitution. The IOM has positioned itself as the organisation which is able to help address mixed migration through a "comprehensive approach" that takes into account protection, assistance and service needs.

Although the concept of mixed migration was first developed by UNHCR, the IOM has since adopted this term and has subsequently highlighted how the challenges of mixed migration fit directly with its work of "assisting migrants and supporting governments" in migration management. The IOM has also cited that its extensive experience in the field of migration, frequently working with complex migration phenomena, forms a solid base on which to develop its approach to mixed migration. The IOM placed itself firmly behind the term, declaring in a 2010 report that the "future of migration is mixed" [25]. IOM believes, that the future of migration is mixed, that trends in irregular movement across the regions will continue to grow in scale and importance. IOM believes that regardless of their status as regular or irregular, all migrants are entitled to protection of their human rights [26].

\section{Conclusions: LATEST DEVELOPMENTS AND TRENDS}

The challenges of increasing mixed migration flows became a matter of great concern for international community. We can find two principle trends in the attempts to cope with the challenges.

The main tendency of mixed migration challenges solutions is approaching the issue from the position of sustainable development, same time looking for benefits it is bringing. Decades of researches and negotiation resulted in 
adopting a number of strategic documents, aimed at resolving problems of mixed migration.

One of such documents is the 2030 Agenda for Sustainable Development [27], adopted by the Resolution of the UN General Assembly No 70/1 in 2015. In this document the positive contribution of migrants for inclusive growth and sustainable development is recognized, as well as the fact that international migration is a multidimensional reality of major relevance for the development of countries of origin, transit and destination, which requires coherent and comprehensive responses [28].

Another tendency that could be distinguished is globalization of cooperation in the field of mixed migration. According to the Annex II "Towards a global compact for safe, orderly and regular migration" of the UN GA resolution 71/1 [28], in 2016 a process of intergovernmental negotiations leading to the adoption of a global compact for safe, orderly and regular migration was launched. This global compact is supposed to set out a range of principles, commitments and understandings among Member States regarding international migration in all its dimensions. It would make an important contribution to global governance and enhance coordination on international migration. It would present a framework for comprehensive international cooperation on migrants and human mobility. It would deal with all aspects of international migration, including the humanitarian, developmental, human rights-related and other aspects of migration. It would be guided by the 2030 Agenda for Sustainable Development and the Addis Ababa Action Agenda of the Third International Conference on Financing for Development, and informed by the Declaration of the High-level Dialogue on International Migration and Development adopted in October 2013.

\section{REFERENCES}

[1] English Oxford Living Dictionaries [Electronic resource]. - Retrieved from: https://en.oxforddictionaries.com/definition/migration

[2] Handbook on Migration Terminology [Electronic source]: International Organisation for Migration, 2011. - Retrieved from: http://publications.iom.int/system/files/pdf/handbook_on_migration_ter minology.pdf?language $=$ en

[3] J. Crisp, "Beyond the nexus: UNHCR's evolving perspective on refugee protection and international migration," UNHCR Research Paper No. $155,2008$.

[4] History of UNHCR: A Global Humanitarian Organisation of Humble Origins [Electronic source]; UNHCR, 2017. - Retrieved from: http://www.unhcr.org/pages/49c3646cbc.html

[5] G. Loescher, "The UNHCR and World Politics: A Perilous Path," Oxford: Oxford University Press, 2001.

[6] "Asylum in the Industrialised World," in The State of The World's Refugees 2000: Fifty Years of Humanitarian Action, ed. by M. Cutts, Oxford: Oxford University Press, p. 161.

[7] A. Geddes and Ch. Boswell, "Migration and Mobility in the European Union," Basingstoke: Palgrave Macmillan, 2011.

[8] A. Zolberg, "Why Not the Whole World? Ethical Dilemmas of Immigration Policy," Amer. Behav. Scient., vol. 56 no. 9, 2012. p. 1209.

[9] S. Castles and M. Miller, "The Age of Migration: International Population Movements in the Modem World," New York: Guilford Press, 1993.
[10] A. Geddes, "The Politics of Migration and Immigration in Europe," London: Sage Publications, 2003.

[11] S. Castles, "The politics of exclusion: asylum and the global order," Metropolis, vol. 8, 2008, p. 3.

[12] UNHCR, "Statement by Mr. Ruud Lubbers, United Nations High Commissioner for Refugees, to the Third Committee of the United Nations General Assembly," New York, 19 November 2001 [Electronic source]. - Retrieved from: http://www.unhcr.org/3bfa5a624.html

[13] S. Hess, "ICMPD: We are Facilitating States," in The Politics of International Migration Management ed. by M. Geiger and A. Pécoud, Hampshire: Palgrave Macmillan, 2010.

[14] UNHCR, "The State of the World's Refugees: In Search of Solidarity," 2012, p. 10.

[15] G. Loescher and J. Milner, "The Missing Link," Int. Affairs, vol. 79 no. 3, 2003.p. 4.

[16] N. Van Hear, R. Brubaker and T. Bessa, "Managing mobility for human development: the growing salience of mixed migration," Human Development Report, UNDP, 2009, p. 1.

[17] S. Castles and N. Van Hear, "Developing DFID's Policy Approach to Refugees and Internally Displaced Persons: Consultancy Report and Policy Recommendations," The Refugee Studies Centre, 2005, p. 27.

[18] UNHCR, "Statement by António Guterres, United Nations High Commissioner for Refugees, to the Third Committee of the General Assembly, 64th Session, United Nations Headquarters," November 2009 [Electronic source]. $\quad-\quad$ Retrieved from: http://www.unhcr.org/4af2e5249.html

[19] M. J. Gibney, "The Ethics and Politics of Asylum: Liberal Democracy and the Response to Refugees," Cambridge: Cambridge University Press, 2004, p. 2.

[20] G. Loescher and J. Milner, "UNHCR and the Global Governance of Refugees," in Global Migration Governance ed. by A. Betts, Oxford: Oxford University Press, p. 197.

[21] United Nation, "Statement by Mr. Ruud Lubbers, United Nations High Commissioner for Refugees, to the Third Committee of the United Nations General Assembly," November 2002 [Electronic source]. Retieved from: http://www.unhcr.org/3dcf8e0f4.html

[22] "Challenges of Irregular Migration: Addressing Mixed Migration Flows," IOM, 2008, Ninety-Sixth Session.

[23] “Regional Strategy 2013-2014,” IOM Regional Office for East and Horn of Africa, p. 3.

[24] IOM, UNHCR Organize Mixed Migration Meeting in Mozambique: Press Room [Electronic resource], IOM May 27th 2014. Retrieved from: https://www.iom.int/cms/en/sites/iom/home/news-and-views/pressbriefing-notes/pbn-2014/pbn-listing/iom-unhcr-organize-mixedmigrati.html

[25] IOM, "Irregular Migration and Mixed Flows: IOM's Approach," Ninety-Eighth Session, p. 1.

[26] Regional Mixed Migration Program in the Horn of Africa [Electronic source]. $\quad-\quad$ Retrieved from: https://www.iom.int/sites/default/files/our_work/DMM/MAD/MixedMigration.pdf

[27] UN GA res. 70/1. 25 September 2015 Transforming our world: the 2030 Agenda for Sustainable Development [Electronic source]. - Retrieved from:

http://www.un.org/ga/search/view_doc.asp?symbol=A/RES/70/1\&Lang $=\mathrm{E}$

[28] A.K. Abashidze, A.M. Solntsev, E.V. Kiseleva, A.E. Koneva, D.A. Kruglov, "Achievement of Sustainable Development Goals (2015-2030): International legal dimension," Indian Journal of Science and Technology, Vol 9(37), DOI: 10.17485/ijst/2016/v9i37/102168, October 2016, p. 1-9.

[29] UN GA res. 71/1, 19 September 2016. New York Declaration for Refugees and Migrants [Electronic source]. - Retrieved from: http://imldb.iom.int/_layouts/15/IML.Portal/AppPages/International.asp $\mathrm{x}$ ?QueryCurrentLang=English 